\title{
HANNE VEBER
}

\section{ERINDRINGER OM UCAYALI}

De historieløses historier

En fælles historie er et vigtigt element i dannelsen af nationer og ,folk“. Fortællingen om en fælles fortid hjælper til at binde menneskene sammen i det, Benedict Anderson har kaldt ,forestillede fællesskaber“" (Anderson 2001). Den historie om fortiden, som fællesskabet gør til sin, er imidlertid - ligesom fællesskabet selv - ikke noget, der findes ,af sig selv“. Historien konstrueres i en proces, hvor der selektivt huskes noget og glemmes noget andet. Hvad der fortælles, er naturligvis ikke tilfældigt; for selvom historien måske ikke er identisk med en sandhed om, ,hvad der virkelig skete“, er den på den anden side heller ikke „opfundet“ ud af den blå luft. Når der fortælles om fortiden, må det i et eller andet omfang korrespondere med erfaringer, folk enten selv har gjort sig eller har gjort til deres, fordi andre, der stod dem nær, har videregivet oplevelser, gode og dårlige, på måder, der kaldte på empati og indlevelse. Historier, der ,virker“, og som huskes og overleveres, må altså have en slags klangbund i forhold til noget, folk kan genkende som troværdigt i det univers, de opfatter som deres. I den forstand synes det at være en anerkendt „sandhed“, at historien afspejler en fælles positiv eller negativ erfaringsramme, som er det, der bag om fortællingen binder mennesker sammen. Historie skrives eller fortælles naturligvis ikke uafhængigt af den politiske og socioøkonomiske kontekst, den aktuelt fungerer i. Denne kontekst ændrer sig over tid. Af samme grund synes hver ny generation at ville skrive historien om, lægge nye vinkler til, minimere andre, som før var prægnante, hente alternative elementer frem fra erindringens og kildernes glemsel (se også Jackson 2002). Alt dette er der ikke spor nyt i. Det er velbeskrevet og vel teoretiseret. Det samme gælder kun delvis processen, hvor „nye“ folk eller nationer skaber sig som, netop, „folk“ og skaber sig den historie, der ,passer“ til den givne kontekst og til den ,identitet“, der fremelskes.

Nogle af disse „nye“ folk hører til den kategori, Eric Wolf engang betegnede som „de historieløse“" (people without history), dvs. folk, hvis historie begrænser sig til det, som fremmede, andre“, som regel koloniherrer, nu- eller forhenværende, har fundet for godt at berette $^{1}$ (Wolf 1982). Men hvordan kan vi nu vide, om disse folk faktisk eksisterer som „folk“ - som forestillede fællesskaber? Og hvis de gør, har de så overhovedet en fælles historie, som er en anden end den, kolonimagterne fortalte om dem? Findes „historie“ $\mathrm{i}$ denne forstand et eller andet sted i en kollektiv erindring, hvor den blot venter på at blive fortalt eller skrevet ned, så den kan blive til en ,rigtig“ historie? Svaret er et nej og et ja. 
Som Bernard E. Jensen fremhæver i sin artikel i dette nummer af Tidsskriftet Antropologi, er „,kollektiv erindring“ ikke et mekanisk vedhæng til en gruppe; menneskers erindringer er nemlig både sociale og konstruerede, dvs. de bliver til på baggrund af interaktion mellem mennesker. Historiebevidsthed, eller opmærksomheden på, at samfund og menneskeligt fællesskab dannes over tid i et socialt samspil, udvikles netop i forlængelse af eller samtidig med udviklingen af en politisk bevidsthed og handlingssammenhæng rettet mod at sikre det sociale fællesskabs form og indhold i en bestemt kontekst, som blandt andet Terence Turner har vist (1988). En orientering mod handling og politisk autonomi gennem tilegnelse af et eget rum for udfoldelse i nutiden kalder på en tilsvarende tilegnelse af fortiden, hvor man peger på, hvordan fundamentet for nutidens „,vi“ blev skabt af „dem, som gik forud“, som samme af slagsen, dem, som skabte „vores“ verden. Det er baggrunden for behovet for selvstændige historietolkninger i en afkoloniseringsproces. Det er med andre ord ikke tilfældigt, at begrebet om „kollektiv erindring“ $i$ anden sammenhæng er blevet defineret som "de dele af fortiden, som forbliver del af gruppens nutidige liv, eller det, som gruppen gør fortiden til" (Hoffmann 2002:135, n. 1). Spørgsmålet er derfor i første omgang, hvem gruppen er; findes den som „gruppe“, som fællesskab?

Som forestillede fællesskaber er grupper og ,folk“ jo ikke på forhånd givne størrelser. De skabes i en aktiv politisk og social proces, som går i gang under bestemte historiske omstændigheder. Nærlæser man denne slags processer, bliver det tydeligt, hvordan disse fællesskaber kommer til syne og skaber deres identiteter gennem en politisk aktivisme, som kalder på historisk hukommelse og lader mennesker, der måske før levede som tavse ( muted i Ardeners forstand ${ }^{2}$ ) og umyndiggjorte på livets skyggeside, komme til orde med fortællinger om, hvem de er, hvor de kommer fra, og hvor de er på vej hen. Forbindelsen mellem politisk aktivisme, identitet og historisk hukommelse bliver især tydelig, hvor det for sammenbragte grupper som fx bortløbne afrikanske slaver på Colombias stillehavskyst (Hoffmann 2002) eller små autonome grupper af amazonindianere lykkes at etablere kollektive identiteter, der overskrider lokale forskelle i sprog, dialekt og geografisk tilhørsforhold.

Asháninkaerne i Perus centrale Amazonas er et eksempel af denne art. De er først i nyere tid blevet kendt som ,asháninka“. ${ }^{2}$ Tidligere bestod de af spredte lokalgrupper, som hver især identificerede sig enten gennem navnet på det vandløb eller den lille biflod, hvor de boede, eller gennem navnet på den lokale leder, de sluttede op om. Siden det 17. århundrede blev de betegnet af de spansktalende missionærer og koloniherrer som „,campa“, en betegnelse, indianerne selv aldrig tog til sig som deres, og som de forstod som nedsættende. Det er først fra 1980'erne og frem, at selvidentifikationen som asháninka bliver slået fast udadtil og får status som den officielt anerkendte betegnelse for disse folk. ${ }^{3}$ Drivkraften i denne selvidentifikation på tværs af lokalgrupper er de nye indianske organisationer, som er dannet på regional basis for at sikre de rettigheder til jord og anerkendelse, som indianerne fik papir på med en lovgivning om indianske rettigheder i $1974 .{ }^{4}$

Vi skal i det følgende se på, hvordan asháninkas historie, eller rettere historier, fortælles af dem selv, og på hvem, der fortæller hvilke historier, og hvordan de fortæller dem. Herved kan vi måske få et indblik i, hvordan historien ser ud „nedefra“, fra asháninkas perspektiv, og hvordan bestemte hændelser i fortiden huskes (eller glemmes) og ordnes narrativt på en sådan vis, at de kommer til at reflektere ikke blot fortiden, men også de problemer, sociale forhold og potentialer for handling, som er relevante $\mathrm{i}$ fortællerens samtid. Vi skal koncentrere os om historier fra Ucayali, regionen omkring et af Amazonflodens hovedtilløb af samme navn, en region, som har været og er skueplads for dramatiske begivenheder 
knyttet til økonomiske eventyr, der i det uendelige har animeret menneskers mindre flatterende sider.

\section{Amazoniske historiciteter og familiære erindringer}

Asháninka bebor det centrale Perus amazonområde, Selva Central, hvor de fra gammel tid har levet spredt i bjergskoven over mere end $100.000 \mathrm{~km}^{2}$ mellem floderne Pachitea i nord, Apurimac i syd, Chanchamayo i vest og Tambo-Ucayali i øst. Befolkningen tæller i dag op mod 90.000 og er en af de største eller måske den største nulevende indfødte befolkningsgruppe i Amazonas. Befolkningstallet har været støt stigende gennem de seneste årtier. Selvom befolkningen deler en fælles traditionel kultur, sprog og kosmologi, er der ikke tale om en homogen gruppe. En meget forskellig og ujævn koloniseringsproces i de forskellige regioner har gjort, at der i dag er stor variation i livsvilkår fra det ene lokalområde til det andet. Nogle asháninka bor, hvor der er tætte forbindelser til de små byer og nybyggerkolonier, som er vokset frem i løbet af det 20. århundrede. Andre lever fortsat isoleret i sværttilgængelige egne. Nogle taler kun asháninka, andre er tosprogede og taler også spansk. Nogle lever i en subsistensøkonomi, andre dyrker salgsafgrøder eller tager lønarbejde på plantager og i tømmerindustrien eller andre typer af betalte småjob. Ganske få har en uddannelse, gerne som tosprogede skolelærere eller sundhedsarbejdere.

Asháninka må siges at høre under kategorien „,historieløse“, i den forstand at deres historiske fortid primært har været beskrevet udefra, dvs. af fremmede. I denne historiefortælling er de blevet fremhævet som amazoniske ,vilde“, der i kolonitiden gjorde snesevis af franciskanermissionærer til martyrer, og som rejste sig i et massivt oprør i 1742 ledet af en inkamestiz kendt som Juan Santos Atahualpa (se fx Valcarcel 1946; Veber 2003). Oprøret fordrev alle missionærer, nybyggere og koloniale autoriteter fra hele Selva Central, som siden forblev uden for den spanske kolonimagts kontrol. Efter Perus uafhængighed rekoloniseres området fra midt i 1800-tallet og frem, og billedet af asháninka skifter fra fremstillingen af dem som „oprørske vilde“ til et, hvor de bliver bipersoner i historien, nogen, som ,står i vejen“ for udviklingen, og som historieskrivningen i øvrigt ikke beskæftiger sig synderligt med.

Asháninkas historier om sig selv udgør en del af en oral tradition, som dels består af fortællinger om historiske begivenheder i lokalsamfundene og dels af beretninger om særlige tildragelser i forældres og bedsteforældres personlige livsforløb. Ved siden af disse mundtligt overleverede historiske fortællinger - historiske, fordi de refererer til hændelser og forhold, som helt eller delvis kan verificeres på basis af andre typer kilder - findes en rig serie af fortællinger af mytisk karakter, der beretter om verdenens og himmellegemernes skabelse og om forholdet mellem mennesker, dyr, planter, naturfænomener (klippestykker, floder m.v.) og spirituelle væsener og om transformationer frem og tilbage mellem de forskellige fremtrædelsesformer, som alle væsener, mennesker inklusive, kan antage. Disse mytologiske fortællinger er fælles for alle asháninka. Det samme gælder ikke de historiske fortællinger og familiehistorierne. De sidste hører, som betegnelsen antyder, til bestemte familier, mens de historiske beretninger er lokale, i den forstand at de alene fortælles blandt grupper, som er hjemmehørende i det område, hvor de begivenheder, der fortælles om, har udspundet sig. 
Ud over mytologien findes der således ikke en fælles historie, som udgør noget, vi kunne kalde asháninkas historie forstået som en fortælling om begivenheder eller personer, der har haft betydning for alle asháninka. Det betyder ikke, at asháninkas historiebevidsthed alene er at finde i personlige erindringer og familiehistorier. Som flere studier af forholdet mellem myte og historie har vist, udgør myte og historie blandt amazoniske folk ikke alternative former for kodificering af historiebevidsthed, som hører til henholdsvis historieløse (,kolde“) og historieskrivende (,varme“) samfund. Myte og historie udgør snarere fortælleformer, som findes parallelt og supplerer hinanden som to sider af samme sag, og både myter og historiske fortællinger har værdi som historiske vidnesbyrd (Turner 1988; Whitehead 2003). Det vil føre videre, end pladsen tillader, at komme rundt om alle de typer fortællinger og øvrige mekanismer til erindring, som findes blandt asháninka. Jeg skal begrænse mig til at se på nogle enkelte familiehistorier og personlige erindringer, som vedrører et bestemt sted i asháninkas historie og aktuelle samtid, nemlig Ucayali, området omkring en af hovedtilløbsfloderne til den mægtige Amazonflod i det centrale Peru. Området har været og er stadig skueplads for noget, man - bevidst om en vis risiko for at blive mistænkt for anakronistisk tænkning - kunne kalde den „rå“ kapitalismes voldtægt af natur og mennesker, som står centralt i samtlige historiske fremstillinger og etnografiske undersøgelser foretaget i nyere tid vedrørende regionen (se fx Santos Granero \& Barclay 2000; Hvalkof 1998). På den baggrund bliver det relevant at finde ud af, hvordan indianerne selv erindrer og fortolker forholdene i Ucayali. Hvorledes korresponderer deres erindringer med studiernes analytiske blik på tingene? Og hvilken betydning har disse erindringer i asháninkas liv og univers? Jeg har haft det held, ${ }^{5}$ at jeg for nylig har fået adgang til nogle familiehistorier, som beretter om forældres og bedsteforældres færden i Ucayali i begyndelsen af 1900-tallet. Lad os til en begyndelse se, hvad en af disse familiehistorier kan fortælle (af hensyn til overskueligheden gengives dele af den som referat): ${ }^{6}$

Min bedstefar hed Mokatzari. Han var fra Mankoite. ${ }^{7}$ Han havde en masse huller i underlæben, hvor han satte fjer, patronhylstre og små pinde, når han ville være fin. Derfor kaldte de ham Mokatzari - det betyder 'små huller'. Omkring 1920 var han på en jagtekspedition sammen med nogle andre fra Mankoite gået over bjergene ved Pitzaflodens udspring. Efter mange dages vandring kom de ned til Cushireni ved Tambofloden. Der forelskede han sig i min bedstemor Shina. De andre gik hjem igen til Mankoite. Min bedstefar blev boende i mange år i Cushireni sammen med min bedstemor, og de fik fire børn, Lucia, som blev min mor, Berta, Eliceo og Nicolás.

En dag kom der nogle ashéninkaer, som opfordrede min bedstefar til at tage med til Masisea for at samle gummi og tømmer. Én af dem, en fætter til min bedstefar, havde kontakt med nogle mestizer, som købte børn, og han overtalte min bedstefar til at tage med for at arbejde for disse mestizer. Og min bedstefar rejste så med min bedstemor og de fire børn ned ad floden på en tømmerflåde for at mødes med disse børneopkøbere. De kom til Masisea, som dengang var en lille landsby. Der blev de i flere måneder sammen med de andre, så de udgjorde en lille gruppe ashéninka. På et tidspunkt kom min bedstefar op at slås med nogen af de andre under en masatofest. ${ }^{8}$ Det gik så vidt at de begyndte at skyde på hinanden med pile, og min bedstefar vandt. De var uenige om et eller andet, der havde med arbejdet at gøre. Senere lagde de andre så en fælde for min bedstefar. Nogle af mestizerne, som slog folk ihjel og solgte børn, rottede sig sammen med nogle onde asháninka og beskyldte den lille Eliceo, min onkel, for hekseri, og de ville have, at min bedstefar skulle sælge drengen til børneopkøberne, ellers ville han blive slået ihjel og brændt som heks. Min bedstefar forsøgte at dræbe børneopkøberen, men hans folk var for mange for 
ham, og det endte med, at de overmandede min bedstefar og bandt ham til et træ. Derpå førte de drengen med sig i en båd med hans hænder bundet fast inde i båden. Og ingen så nogensinde mere den stakkels Eliceo.

Sådan indleder Bernardo Silva Loayza den beretning om sit liv, som han gav mig i efteråret 2004, da jeg var kommet til Atalaya i forbindelse med mit forskningsprojekt om indiansk lederskab med udgangspunkt i en række lederes selvbiografiske fortællinger. Beretningen handler videre om, hvordan det lykkes Mokatzari at flygte fra Masisea med hustruen og de tre tilbageværende børn. Masisea ligger på Ucayaliflodens højre bred et godt stykke neden for Pachiteaflodens udløb. Stedet var på den tid opsamlingsplads for gummi og som sådan også tilholdssted for opkøbernes håndgangne folk. Flugten bliver dramatisk, for den lille familie tør ikke sejle på floden af skræk for forfølgere. Derfor går de igennem sumpene, som er fulde af krokodiller, elektriske ål, giftige padder og andet modbydeligt kryb. Til sidst når de bjergene ind mod Gran Pajonal på den anden side af floden. Herfra kan de krydse over land for at nå frem til deres hjemsted. De stedkendte vil vide, at der mellem Masisea og Cushireni på Tambofloden er en afstand på mere end $500 \mathrm{~km}$ ad flodvejen. Vejen over bjergene er måske lidt kortere, men den går over vanskeligt og stærkt kuperet terræn. I bjergene lurer desuden sultne rovdyr, giftslanger og andre farer, men de er dog i mere velkendte omgivelser, og efter fire måneder, hvor de hugger sig vej gennem bjergskoven, når de tilbage til deres hjemlige boplads. Siden drager de langt op ad Perenéfloden til Sutziqui, hvor der er blevet anlagt en adventistmission. ${ }^{9}$ Her bliver de, selvom Mokatzari slet ikke kan affinde sig med adventisternes regime.

Ved Sutzikifloden var der anlagt en lille landsby, og de fleste, som boede der, var asháninka. Min bedstefar og bedstemor så for første gang, hvordan folk arbejdede med at anlægge en landingsbane, og snart så de en flyvemaskine komme ned fra himlen, og de var fulde af forundring. Ud af maskinen kom nogle gringoer ${ }^{10}$ og mange troede, at det var Gud, for nogen havde sagt, at Gud Tasórentsi var steget ned fra himlen. De levede et stykke tid med denne idé. Senere forstod de, at gringoerne blot var nogle prædikanter, som bragte budskaber fra Gud, og at de kom fra Syvende Dages Adventisternes sekt. De sagde til dem, at man ikke måtte arbejde om lørdagen, [...] og at man hverken måtte spise svinekød eller fisk uden skæl, ligesom man ikke måtte male sig [i ansigtet], drikke masato, føre krig, lave ballade, drikke sig fuld og lyve. Man skulle vise respekt. Det fyldte min bedstefar med afsky. Han lo aldrig mere.

Men ulykkerne er langtfra slut. Hustruen bliver bidt af en giftslange og dør. Mokatzari bliver dybt deprimeret, nægter at tage føde til sig og sidder hen dybt nedbøjet, når han da ikke går amok og skyder om sig med pile. De øvrige indianere i missionen er bange for ham, og til sidst bliver han for stor en belastning. De ser ingen anden udvej end at skaffe ham af vejen, så de kan få fred.

En dag, det var meget varmt, og han var i godt humør, kom nogle mænd og spurgte, om han ikke ville med ned til floden for at bade. Nede ved floden bandt de ham og hængte ham i en lian. Men før han døde, forbandede han sine bødler med ordene: 'Selvom I dræber mig, vil I også dø! En dag vil I dø, kujoner!' Sådan sagde han til dem, og så dræbte de ham.

Børnene er nu alene tilbage. Senere tager datteren Lucia med nogle slægtninge på en ekspedition efter salt fra Saltbjerget længere østpå. På vejen møder hun en mand, med hvem hun bliver boende i det øvre Perené. Her fødes Bernardo i 1947. Han vokser op i 
skoven med bue og pil og dagligt arbejde i svedjen for at skaffe sig livets ophold som bedstefaderen og utallige generationer af asháninka har gjort det før ham. Men han lever ikke helt på den måde i dag. Forskellige omstændigheder bringer ham til Ucayali, hvor han stadig bor. Fra 1996 og seks år frem havde han plads i byrådet i Atalaya, opstillet og valgt på en indiansk liste uden for de etablerede politiske partier. Nu fungerer han som formand for et indiansk kooperativ, der producerer plantemedicin til det peruanske hjemmemarked. Han bor med sin familie i Atalaya og er aktiv både i indiansk regionalpolitik, i den katolske kirke og i udøvelsen af traditionelle spirituelle praksisser forbundet med brugen af tobak og ayahuasca, en lian, hvis afkog er et kendt hallucinogen.

Atalaya er en lille by på flodskrænten over for sammenløbet mellem floderne Tambo og Urubamba, hvor Ucayalifloden tager sin begyndelse. Men Ucayali er ikke blot en flod og en betegnelse på en provins i Peru. Ucayali er også et sted i folks erindring, som Bernardos historie antyder. I daglig tale er Ucayali betegnelsen for en region med en lang historie som den geografiske akse i forskellige ekstraktive ${ }^{11}$ økonomiske fronter, hvor lette og hurtigt tjente penge har stået og står (!) over hensyn til miljø og mennesker. I et land, hvor staten på en og samme tid er centralistisk og svag, har det haft den praktiske konsekvens, at magten i de mere afsides provinser altid har siddet for enden af et gevær, nemlig i den ende, der havde fingeren på aftrækkeren. Ucayali er i dag præget af legal og illegal tømmerhugst, der primært foregår inde i baglandet mellem floderne, og af aktiviteter forbundet med udvindingen af naturgas i det øvre Urubamba. Der er store politiske, sociale og miljømæssige problemer forbundet med disse aktiviteter i form af magtmisbrug, marginalisering af lokalbefolkningen, korruption, gasudslip i flodsystemet og ødelæggelse af flora og fauna og menneskers livsbetingelser. ${ }^{12}$ Befolkningen i regionen udgøres af mestizer af blandet herkomst, efterkommere af de europæiske ,opkøbere“ og investorer og andre iværksættere, der slog sig ned langs floden fra midten af 1800-tallet, nylige indvandrere fra andeshøjlandet og en række indianske grupper, ashéninka, yine, shipibo, conibo, amahuaca og andre, som ,altid“ har boet der. Disse indfødte grupper udgør hovedparten af befolkningen i landdistrikterne uden for de små og mindre byer, som er vokset op i området.

Bernardos historie giver os et indblik i én families fortid, men kun ringe information om den kontekst, hvori den udfoldede sig. Vi skal kort kaste et blik på den historiske fortid, hvis hovedtræk er blevet fremanalyseret i anerkendte studier baseret på undersøgelser af eksisterende skriftlige kilder. Den vil give os en kontekst og baggrund for at forstå Bernardos fortælling.

\section{Koloniseringens økonomiske fronter}

Eksisterende historieskrivning fremhæver to økonomiske fronter, som har formet regionerne i Perus centrale Amazonas, hvor de to fronter har betinget fremkomsten af to hovedtyper af regionale økonomiske systemer. Det ene, baseret på en agropastoral økonomi med produktion af frugt, kaffe og kvæghold, karakteriserer i dag de højereliggende områder i montañaen (Perené-Chanchamayo-Satipo) vest for Ucayali. Det andet, baseret på ekstraktive økonomier, er fremherskende i Ucayali og i selve amazonlavlandet mod øst (se Santos Granero \& Barclay 1998, 2000). Asháninkas territorier strækker sig over begge regioner. Det er derfor ikke underligt, at de historiske fremstillinger af indianernes situation oftest fremhæver, at asháninka er blevet klemt mellem de to økonomiske fronter, som 
omklamrede dem fra henholdsvis vest og øst fra midten af 1800-tallet og frem (Brown \& Fernández 1991; Hvalkof 2004).

I områderne mod vest i det øvre Perené nærmest på Andesbjergene skete en kolonisering med nybyggere, som gradvis tilegnede sig jorden og fordrev mange af de asháninka og yánesha, ${ }^{13}$ som boede der. De indianere, som valgte at blive, så sig hurtigt låst fast på små jordlodder, som var og er helt utilstrækkelige både i forhold til at opretholde en traditionel subsistensøkonomi og til at leve af at producere afgrøder til salg. Disse asháninka er i dag integreret i regionens agropastorale økonomi som fattiggjorte småbrugere og sæsonarbejdere, marginaliserede i deres eget hjemland. Blandt disse grupper findes historiske fortællinger, som dels beretter om en glorværdig fortid, hvor de kæmpede mod den spanske kolonimagt og havde held med det, og dels om, hvordan det siden lykkedes den peruanske hær at narre indianerne til at nedlægge våbnene ved at give dem rigelige gaver i form af eftertragtede industrivarer. Herefter var der åbnet for nybyggerkoloniseringen, og resten af historien handler så om kampen for ret til jord og egen kultur og sprog.

De asháninka, som valgte at flytte mod mere afsides egne, i takt med at deres livsbetingelser blev forringet gennem koloniseringen, dannede enten nye lokalsamfund, eller de indgik i allerede eksisterende lokalsamfund i de nye områder. De historier, jeg har fået fra sådanne udflyttere, er typisk familiehistorier uden den grad af generalitet, som gælder for de historiske fortællinger, der verserer i det øvre Perené. Asháninka hjemmehørende i de østlige områder nærmere det lavereliggende flodland fortæller ikke historier om den spanske kolonitid eller om den peruanske hærs komme. Det hænger formentlig sammen med, at sammenstød med spanske hærstyrker i nedre Perené og videre mod øst i 1700tallet har været få og sporadiske og uden markante langvarige konsekvenser set fra et lokalt perspektiv. De er altså blevet glemt. Det, som fortælles, er beretninger om koloniseringen i det 20. århundrede, men det er fortællinger om bestemte nybyggere og om bestemte asháninkafamilier, ikke om asháninka eller nybyggere generelt. Det hænger muligvis sammen med, at koloniseringen foregik kaotisk og spontant drevet af private eller gejstlige (katolske) initiativer. Der var aldrig tale om en større overordnet plan, som omfattede en hel region. Koloniseringen foregik stykvis og diskontinuert blandt en indfødt befolkning, som var decimeret gennem gentagne epidemier og morderiske angreb fra anden side, som vi skal se. Det, som kunne erfares og huskes, har med andre ord haft præg af lokale individuelle hændelser mere end af begivenheder, der på én gang berørte en bredere etnisk baseret kollektivitet og kaldte på fælles modstand. Måske er det ikke så underligt, at historierne her har karakter af familiehistorier, hvis potentialer for sammentænkning inden for en fælles historisk fortælling hidtil er forblevet uudfoldede. Det samme gælder fortællingerne fra Ucayali, som tidligere var et grænseområde i periferien af asháninkas territorier, et sted, mænd tog hen til for at handle, men ikke et sted, hvor mange asháninkaer boede fast.

Ucayali var i fordums tider domineret af yine- (piro), shipibo- og coniboindianere, og området blev center for gummihandelen, som i årtierne før og efter forrige århundredeskifte var et af den ekstraktive økonomis mest markante højdepunkter. Dette såkaldte ,gummiboom“ kom til at involvere en mængde asháninka, som på forskellig vis blev trukket til området, frivilligt og ufrivilligt. Sammen med den gradvise udflytning af asháninka fra de tættest koloniserede områder mod vest skulle gummiboomet således vise sig at medføre en stigende bosættelse af asháninka i Ucayaliområdet. Historien om denne demografiske og territoriale ommøblering af mennesker udgør et hidtil underbetonet aspekt af gummi- 
boomets historie. Men det skal vi ikke komme ind på her. Historien om gummiboomet i sin konventionelle udformning handler ikke primært om asháninka. Sådan som historien er skruet sammen, er indianerne bipersoner; de er arbejdskraften, de tavse hænder, der udfører de handlinger, som historiens ,virkelige“ aktører beslutter og sætter i værk.

Den konventionelle historie om Ucayali er først og fremmest en historie om verdensøkonomi og en dramatisk stigning i efterspørgslen på rågummi, som tog sin begyndelse i sidste halvdel af 1800 -tallet og endte omkring 1. verdenskrig. Da var det nemlig lykkedes englænderne at smugle gummiplanter fra Amazonas til deres kolonier i Sydøstasien, hvor planterne viste sig at trives, og hvor man snart havde gang $\mathrm{i}$ en stor gummiproduktion $\mathrm{i}$ plantagedrift. ${ }^{14}$ Det amazoniske gummiboom udvikledes som følge af to teknologiske opfindelser, som for en tid gjorde Amazonas, hvor forskellige arter af gummitræer (primært varianter af Hevea og Castilloa) vokser naturligt, til verdens vigtigste leverandør af rågummi. I USA havde Charles Goodyear opfundet vulkaniseringsprocessen i 1839, og den voksende bilindustri begyndte efterhånden at efterspørge gummidæk til deres automobiler. Det gav gode priser på gummi på verdensmarkedet. Da indførelsen af dampskibet yderligere gjorde det muligt at organisere eksporten af rågummi fra Amazonas i store mængder, blev handelen med produktet for alvor lukrativ.

Indsamlingen af rågummi blev organiseret gennem et netværk med udenlandske og peruanske investorer og handelsmænd i toppen knyttet til forskellige magtfulde handelshuse med baser i Iquitos, som voksede op som den største og mest velhavende by i det peruanske lavlandsamazonas. Under handelsmændene stod andre netværk af opkøbere og gummisamlere, alt organiseret i et hierarkisk system med den indianske arbejdskraft i bunden. De høje priser på verdensmarkedet gjorde gummihandelen yderst profitabel for dem, som sad i toppen. Indsamlingen af gummi beroede på tilstedeværelsen af indiansk arbejdskraft. Indianerne kunne selv finde rundt i skoven og lokalisere de værdifulde træer, de var stort set selvforsørgende og selvforsynende med transport; de var således billige i drift. Desuden var der ikke mange andre at trække på som arbejdskraft. Indianerne var med andre ord alfa og omega i gummihandelen. Lokale indianere lod sig gerne hyre for korte perioder, så de kunne tjene til at erhverve sig eftertragtede goder som metalredskaber, geværer og andet. Men når dette var opnået, var de tilbøjelige til at forlade arbejdet og rejse hjem, som det passede dem. Det var med andre ord et problem at fastholde dem.

Løsningen kom til at bestå i to ting: For det første sørgede gummi,,patronerne "“15 (dvs. dem, der kontrollerede handelen og indkasserede fortjenesten) for at gældsætte indianerne og opretholde en gæld, som de vedblivende måtte arbejde af på. Systemet bestod i at udbetale forskud på betalingen for arbejdet, forskud, som hver enkelt indianer måtte arbejde af ved at levere et af patronen fastsat kvantum gummi til en bestemt tid. Herefter faldt et nyt forskud, som derpå måtte arbejdes af, og så fremdeles. Da det imidlertid alene var patronen, der bestemte den relative værdi af den leverede gummi og det udbetalte forskud, som altid var i form af naturalier, viste det sig næsten altid på regnskabets dag, at indianeren stadig skyldte arbejde. Systemet udgjorde en form for gældsslaveri. For at sikre, at de gældsatte ikke løb bort og gemte sig, oprettedes et terrorregime, som gennem grusomme metoder (drab, mishandlinger og alle hånde former for fysisk og psykisk intimidering) kontrollerede indianernes gøren og laden og hindrede deres fri bevægelighed. ${ }^{16}$

For det andet udvikledes et forsyningssystem som en selvstændig økonomi ved siden af gummihandelen, hvor patronerne udliciterede plyndringer af indianske bopladser og 
bortførelser af kvinder og børn, som så blev overgivet til patronerne. Underleverandørerne, som stod for disse aktioner, kunne være både mestizer og indianere, som enten arbejdede selvstændigt eller selv var underlagt en patron. De bortførte børn voksede op hos patronerne og blev oplært som deres loyale arbejdere. Kvinderne fødte nye børn (med patronerne som fædre), som indgik i systemet som fremtidige loyale undergivne. Indianerne indgik i alle led i disse økonomiske fødekæder, dvs. både som ofre for bortførelser og plyndringer og som dem, der udførte dem - på egen hånd eller sammen med mestizer i patronernes tjeneste, som Bernardos fortælling om bedstefaderen er et eksempel på. Der var ikke så meget at vælge imellem; ville man ikke være blandt ofrene, måtte man skaffe sig adgang til skydevåben. Og den eneste måde, hvorpå disse kunne erhverves, var gennem arbejde for patronerne, evt. som „skaffer“ af børn og anden arbejdskraft.

Der findes masser af øjenvidneskildringer af disse forhold hentet i nedskrevne beretninger fra opdagelsesrejsende og missionærer, som i denne epoke rejste på Ucayali og dens tilløbsfloder (se fx Sala 1925; Samanez y Ocampo 1980). Disse mennesker stod i iagttagerens position; de havde ikke selv direkte del i systemet, og deres beskrivelser er præget af den fremmedes nøgterne afstand til det observerede. Hvorledes deltagerne $\mathrm{i}$ systemet selv forstod tingene, ved vi meget lidt om. Der har manglet nedskrevne beretninger fra indianernes side om forholdene. Men hvad er det så for en historie, Bernardo fortæller om gummiboomets verden? Fortæller han en „offerhistorie“? Eller det modsatte, en heltehistorie? Eller er det noget helt tredje, han er i færd med?

\section{Erindringernes fortællinger}

Når Bernardo fortæller historien om bedstefaderen, fortæller han den ikke som en slægtshistorie slet og ret, for i Bernardos egen livshistorie vender han tilbage til spørgsmålet om, hvad der mon blev af den lille Eliceo. Det sker på det sted i historien, hvor han fortæller om, hvordan han midt i 1980'erne beslutter at flytte hele sin egen børnerige familie fra det øvre Perené til Ucayali. I Ucayali var der frit land, siger han, hvor man kunne slå sig ned, og der var masser af dyr i skoven og fisk i floderne i modsætning til situationen i Perené, hvor det hele for længst var koloniseret af nybyggere, og vandet $\mathrm{i}$ floden var forurenet af kemikalieaffald fra minerne i Andes, så alle fiskene var døde.

Jeg hørte nogen sige, at der var masser af fisk i Atalaya, og så kom jeg til at tænke på mine onkler Nicolás og Samuel, som for mange år siden var flygtet tilbage til Tambo, og på ham, som var blevet solgt af de onde mordere, mestizer og asháninka, sådan som min mor fortalte mig, da jeg var lille ... Siden kom jeg til at kende Atalaya, Tambofloden og Urubamba, og de steder kunne jeg lide. Der var masser af fisk, vilde dyr, fugle, jord, og træer.

Men Bernardo flytter ikke blot til en fremmed egn som en anden nybygger. Det er vigtigt for ham at understrege, at han flytter til et sted, hvor andre $i$ hans familie har færdedes før ham, og han har jo så i den forsvundne Eliceo en slægtning et eller andet sted i Ucayali - selvom ingen har hørt eller set noget til ham i mere end et halvt århundrede. I Bernardos optik legitimerer erindringen om den tabte onkel det tilhørsforhold til Ucayali, som hans fortælling er med til at opbygge.

Samtidig er historien om Mokatzari og den tabte søn ikke entydigt en historie om et offer for overgreb. Mokatzari er på en måde selv ude om det. Han er en slagsbroder og en 
kriger, og han opsøger frivilligt banditter, som skal bruge en mand af hans slags i deres overfald på andre folks bopladser, hvorfra de bortfører kvinder og børn. Bernardo ved ikke helt, hvordan han skal forholde sig til dette. I hans første version af historien fremstilles det, som om bedstefaderen er helt med på det, han har indladt sig på. Senere, året efter at vi har foretaget det første biografisk narrative interview, og vi går teksten igennem for at klargøre detaljerne, begynder han at indføje sætninger, der handler om, at bedstefaderen er imod disse bortførelser, og at det er årsagen til uenigheden mellem ham og de andre indianere i Masisea. Bernardo er tydeligvis kommet i tanker om, at det måske ikke er heldigt, at hans bedstefader fremstår som barnerøver nu, hvor historien kommer til at stå på tryk, så alle og enhver kan læse den. Billedet af bedstefaderens voldsomme temperament og krigeriske tilbøjeligheder fastholdes dog i fortællingen om hans vanvid efter hustruens pludselige død.

Folk var meget bange for ham, efter at han var blevet vanvittig, fordi han begyndte at skyde om sig med pile, ligesom han havde gjort, mens han var rask, dengang han som en meget stærk kriger førte an i bagholdsangreb.

Selv efter at han er blevet slået ihjel, fortsætter bedstefaderen med at plage sine omgivelser:

Da der var gået tre dage, brændte de den døde, for om natten hørte folk en masse spektakel, som om han stadig var levende. Derfor brændte de ham, og da de havde gjort det, blev der atter fred om natten, sådan som det havde været, før de dræbte min bedstefar.

Bedstefaderen var altså en ballademager i en sådan grad, at end ikke døden kunne bringe ro over ham. Men han var ikke bare en ballademager. Hans styrke var ikke kun fysisk, den var også mental og åndelig. Mokatzari viste viljestyrke og talte sine fjender midt imod, „talte stærke ord“, som man siger blandt asháninka, og ikke mindst var han en ansvarsbevidst og omsorgsfuld familiefader, idealer, som Bernardo sætter højt og selv søger at efterleve. Som kriger og slagsbroder er Mokatzari ikke noget typisk offer, og Bernardos beretning om den forsvundne Eliceo er ikke bare en offerhistorie fra gummiboomets tid. Den er lige så meget en historie om Bernardo selv og om voldens paradoksale uhensigtsmæssighed/nødvendighed. Mokatzari voldelige tilbøjelighed er årsag til hans problemer; volden, drabet på ham, er også det nødvendige middel til at skabe fred og orden.

Historien kunne formentlig have været fortalt anderledes, enten som en mere entydig offerfortælling eller måske som en fortælling om Mokatzari som den store kriger. Det sidste kunne tænkes, i og med at der faktisk eksisterer en narrativ genre omkring krigerhistorier, ${ }^{17}$ ligesom det på det seneste er blevet almindeligt blandt asháninka at tale om, at „tidligere var vi krigere“, eller ligefrem ,vi er jo i virkeligheden krigere“! Denne slags tale hørte man aldrig i 1980 'erne. ${ }^{18}$ Dengang ville selv ældre mænd, som havde ar efter gamle krigsskader og store samlinger af buer og pile siddende parat under taget, bedyre, at krig sandelig var noget, de aldrig kunne finde på at deltage i. Næ, krig var noget, forfædrene havde kørende. "I dag er vi meget meget fredelige!", ville de sige - med et rævekagegrin på læben. $\mathrm{Nu}-20$ år og en krig $^{19}$ med og mod to oprørsbevægelser senere - taler ingen mere om asháninkaerne som fredelige. I fuld offentlighed kan det lyde: "Ja, vi er jo ikke så fredelige, som vi ellers går og siger!" Ordene kom fra formandens velkomsttale ved et fællesmøde for asháninka i Tambo i efteråret 2004, hvor der samtidig med ordstyrer og referent blev valgt fire sikkerhedsrepræsentanter, der skulle sørge for, at mødet forløb i god ro og orden. De fire mænd 
var udstyret med automatvåben og holdt vagt døgnet rundt ved indgangsvejene til landsbyen, hvor mødet blev afholdt.

Det gælder om at styre temperamenterne og en hel masse andet. Det indebærer blandt andet, at man må vise styrke og handlekraft, ikke blot blandt asháninka indbyrdes, men også udadtil. Kun på den måde kan man håbe på at holde sig nogenlunde fri af tømmerfirmaernes manipulationer og på afstand af kokainmafiaen og terroristerne, som har lige så meget brug for gratis arbejdskraft i dag, som gummipatronerne havde i sin tid. At vise styrke er lidt et spil for galleriet, hvor pointen er at finde balancen mellem det at spille med musklerne og samtidig undgå at bruge dem - ikke mindst i situationer, hvor de alligevel er utilstrækkelige. Det kræver en vis dødsforagt at kunne køre dette spil overbevisende. En anden af mine informanter, Vicente Naco fra Pangoa, illustrerer attituden med sine egne ord til en patron, som han selv og andre er vrede på i en sådan grad, at de truer med at slå ham ihjel, vel vidende, at de næppe selv vil slippe fra det med livet i behold: „Lad os nu se? Hvem skal dø først? Du eller os? Det er vist bedre, at du dør først!"“ I den pågældende situation, som ligger mange år tilbage, havde truslen den ønskede effekt, hvis vi skal tro Nacos ord. Det var ikke nogen tom trussel. Ñaco sluttede sig til MIR-guerillaen ${ }^{20}$ i 1965 for at gøre en ende på patronernes enevældige magtmisbrug i Pangoa - og han overlevede som en af de få indfødte partisaner. ${ }^{21}$ Med historien om bedstefader Mokatzari indskriver Bernardo sig retorisk i denne krigerdiskurs - på tilpas afstand, men stadig med del i den. Han er ikke selv en mand, der griber til våben; hans virkemidler er diplomatens og shamanens - og det er en anden historie. Men der er også andre typer af erindringer om Ucayali, som har en helt anden karakter.

Historien om Mokatzari har en parallel i en slægtsberetning, som er del af den livshistorie, jeg fik fra Adolfo Gutierrez, en ældre asháninkaleder i det centrale Perené. Adolfo var i sine unge dage kendt og agtet blandt nybyggerne som den bedste bådfører på Perenéfloden, et meget utraditionelt hverv for en asháninka, og han var aktiv i kampen for jorden og den indianske organisering i 1960'erne og 1970'erne, tiden, hvor massive invasioner af nybyggere satte ind. Om sin fader fortæller Adolfo:

Min far hed Andrés Gutierrez Shimuncama. Han var fra Atalaya. Han voksede op hos en patron, der hed Jaime Morón. Patronen havde to koner, men de fik ingen børn. En af dem hed María Gutierrez de Morón, Hun adopterede min far. Derfor kom han til at hedde Andrés Gutierrez. Men hans rigtige navn var Shimuncama. Min far arbejdede for denne patron, som satte ham til at finde folk forskellige steder. Men han skulle ikke søge folk, som så tog med frivilligt, nej, han skulle lave byttehandeler for at skaffe folk til patronen. Han skaffede også piger og drenge, endog ældre mennesker, til patronen. Og sådan arbejdede han i mange år med byttehandeler, hvor han kom med geværer, gryder, ammunition og også bomuldsstof og macheter for at bytte. Denne handel bragte ham til Perené. Han kom en dag til øvre Pichanaki, hvor han havde en kunde, om man så må sige, en kunde, til hvem han gav et gevær; til gengæld skulle denne så bringe ham nogle folk.

På den tid var min mor en lille pige. De boede i Yurinaki. Men så kom mændene fra det øvre Pichanaki og overfaldt dem. De bortførte min mor og hendes tvillingesøster. Søsteren solgte de til nogle tyskere. ${ }^{22}$ En af dem giftede sig senere med hende. Min mor blev taget med til Atalaya, hvor det var meningen, at min far skulle give hende til patronen. Men så sagde min fars kone, som ikke havde nogen børn, til ham: 'Ved du hvad, Andrés, du skal ikke give den pige til patronen. Det er bedre, at vi beholder hende her hos os, så hun kan hjælpe mig med arbejdet. Jeg er jo ved at være gammel. Så kan hun hjælpe med visse ting!' Min far adlød og lod pigen blive. Han beholdt hende selv. Hun voksede op, og da hun blev stor nok, fulgte hun den skik, vi har omkring den første menstruation, hvor hun blev 
afsondret i en lille hytte et stykke tid. Alt blev gjort, som det skulle. Der blev holdt fest, og hun kom ud som voksen kvinde.

Et stykke tid senere sagde min fars kone til ham: 'Andrés, måske skulle du begynde at leve sammen med pigen. Måske får hun et barn!' Og min far adlød igen og prøvede at komme til at leve sammen med pigen, min mor. Men min mor ville ikke, det har hun selv fortalt mig. Men gradvist vænnede hun sig til tanken og til min far. Han var jo gammel på det tidspunkt, helt gråhåret. Min mor blev gravid og fødte en lille pige. Men barnet døde desværre, da hun var en måned gammel. Og hvordan gik det så?

Min far var jo vokset op hos patronen. Patronen hundsede altid rundt med ham: Gør dit og gør dat! Og hvis der var det mindste i vejen, fik min far skylden. Han blev afstraffet, sat i fodlænker og fik pisk. Ideen var, at han skulle afsløre, hvad der var blevet af det, som manglede. Hvis en kano var gået tabt, gik det ud over min far. Han blev afstraffet hele tiden. Den, som reddede ham, var hans hustru. Hun reddede ham gang på gang. Hun gik til patronen, og hun ikke bare råbte og skreg, men hun greb en kæp, som om hun ville forsvare ham, og råbte: 'Slip ham! Slip ham!' Så slap de min far fri. Ikke blot ham, men også min onkel. Han var blevet taget til fange samtidig. Jeg har mange onkler. De var fire brødre og to fætre. Min far var meget træt af det. Han skyldte patronen for nogle geværer. Patronen havde givet ham kassevis af geværer til at bytte med. Derfor skyldte han ham for dem. Men så sagde min far: 'Vi må hellere tage et andet sted hen!' Der var kommet en missionær på den tid. Han var halvt piro [yine] og hed Abel Fieta. Sammen med en anden onkel, også en piro, var han kommet for at bringe os budskabet om evangeliet. Han prædikede Guds ord. Så var det min far sagde: 'Lad os rejse væk! Lad os følge med denne fætter hen, hvor han bor!'

Beretningen fortsætter om, hvordan fader Andrés og hans to koner flygter fra patronen sammen med onklerne og piroprædikanterne. Ad flere omveje ender de i adventistmissionen i Sutziki, hvor de bliver boende. Her fødes med tiden andre to små piger i familien og til sidst, i 1935, Adolfo. Faderen dør, da Adolfo er fem år gammel. Han dør efter sigende af tuberkulose, som man mener, han har fået som følge af patronens mange afstraffelser, hvor han har siddet lænket ude i regn og sol og er blevet våd og stegt. Adolfo vokser op i missionen, hvor han lærer at tale godt spansk og kommer i skole. Efter nogle år finder moderen sig en anden mand og vil flytte bort. Hun vil tilbage til Atalaya, og hun vil have drengen med. Men han nægter:

Jeg tænkte på min fars gæld til patronen, hvad nu hvis ...? Han vil sikkert finde ud af, at jeg er Andrés' søn, og så vil han komme efter mig, for at jeg kan betale gælden. Og hvad kommer jeg så til at bøde for det? Derfor ville jeg ikke med.

Missionærerne lægger pres på ham for at få ham til at følge med moderen. Men han nægter pure. Han er ni år gammel og skrækslagen ved tanken om at skulle til Atalaya. Han vil hellere klare sig selv ved at arbejde i missionen, og sådan bliver det.

Adolfo bruger ikke på noget tidspunkt ord som slave, slaveri, slavejagt. Disse ord er nogen, nutiden har hæftet på fænomenet. I samtiden forstod ingen, hverken patroner eller indianere, de gældende arbejdsforhold som slaveri. Patronen ejede jo ikke arbejderens person, formelt set. Patronen „ejede“ hans gæld. Derfor bruger man ofte udtrykket „gældsslaveri“ om forholdet (se også Gow 1991:66, n. 7). De kvinder og børn, som blev „skaffet" til patronerne, blev ganske vist bortført med vold, men formelt set blev de optaget i patronernes arbejdsstyrke, ikke som slaver, men som medlemmer af hans hushold. Adolfos fader har tydeligvis været en af de mange, som var blevet „skaffet“ til en patron som barn for at vokse op og fungere som velafrettet arbejdskraft. Han var patronens håndlanger, som drog rundt i området og forsynede menneskejægerne med våben, mod at 
de „skaffede folk“ til patronen. Andrés var selv underlagt patronens umenneskelige metoder, og det lykkedes ham først at unddrage sig dennes kontrol, da der blev et sted at søge tilflugt, nemlig i adventistmissionen, hvor tusindvis af indianere på den tid søgte sammen, herunder også Bernardos bedstefader Mokatzari, som vi har hørt om. Adolfos moder blev bortført som barn af menneskejægere, som hans fader selv havde betalt for at gøre det på vegne af patronen. Historien er grotesk. Adolfos beretning om forældrene har i højere grad karakter af offerhistorie, end det var tilfældet med Bernardos historie om bedstefader Mokatzari. Adolfos fader måtte hele sit liv leve med konstante mishandlinger fra patronens side, og han ender tilsyneladende med at dø af følgevirkningerne. For Adolfo er slægtshistorien ikke så meget en udpegning af et etnisk og familiemæssigt tilhørsforhold, som den er en legitimering af hans rodfæstethed i adventistmissionen. Han angiver navne og relationer til missionærer, som har betydet alt for ham, siden han var ganske lille. Han forbliver adventist hele sit liv, og han ser hellere mod vest mod Andesbjergene og Lima og de fremskridt og ændringer, disse steder repræsenterer, end han ser mod øst mod Ucayali og det liv, hans forældre har haft dér, før han selv blev født. I forlængelse af denne orientering mod selvstændig selvopretholdelse bliver Adolfo også aktiv i kampen for indianernes ret til jord og frihed fra dominans fra nybyggerside.

\section{Oplevelsens og erindringernes politik}

Bernardos historie om bedstefaderen og Adolfos fortælling om sine forældre giver os et lille indblik - måske ikke så meget i, hvad der faktisk er foregået i Ucayali for mere end et halvt århundrede siden, men i, hvordan indianerne har opfattet det skete, og hvad forældres og bedsteforældres fortalte erfaringer betyder for de generationer, der kom efter. Bernardos og Adolfos familieerindringer fra Ucayali er vidt forskellige. De lader os ane, i hvor høj grad en tilsyneladende fælles historisk baggrund tolkes forskelligt, både fordi personerne, der fortæller, er forskellige, og fordi de oplevelser, der fortælles om, har været meget uensartede, baseret på meget forskellige roller og indgangsvinkler i forhold til nogle parametre, som trods alt var del af samme historiske fænomen, nemlig gummiboomet. I den forbindelse rejser sig tre spørgsmål: For det første spørgsmålet om, hvorvidt erindringer om gummiboomet overhovedet spiller nogen rolle for indianerne $\mathrm{i}$ dag $-\mathrm{fx} \mathrm{i}$ forhold til deres identitetsdannelse og selvforståelse som asháninka og ashéninka? For det andet om erindringer fra gummiboomets tid udgør en fælles erfaringsramme for indianerne? Deres forfædre var trods alt ikke blot ofre, men også for nogens vedkommende gerningsmænd. Hvorledes fortælles og huskes eller glemmes disse forskellige positioner? For det tredje kan man spørge, på hvilken måde - om overhovedet - disse historier rører ved noget, som angår alle asháninka. Og hvordan lader de sig i grunden binde sammen, analytisk og empirisk i en optik, der overskrider det private familieperspektiv. Hvilken er en sådan optik i givet fald?

Som Kirsten Hastrup har påpeget, udgør erfaringer, som bliver til fortællinger, ikke blot private oplevelser, men sociale forhold: 'I det øjeblik, enkelterfaringer bliver udhævet af den brogede masse af oplevelser og hændelser, vi støder ind i, får de tillagt en betydning, som ikke kan være privat. Betydning etableres altid med henvisning til en kontekst, i forhold til hvilken relativ signifikans afgøres" (1999:271). Det samme gælder for erindringer; deres vigtigste kvalitet er faktisk deres ikke-tilfældighed. Deres betydning er ikke kun 
retrospektiv, men afspejler erindringens signifikans i den kontekst, hvor den fortælles (ibid.).

Antropologen Peter Gow har beskrevet, hvorledes yineindianerne i Ucayali og Urubamba (i ældre litteratur kendt som „piro“) i dag taler om gummiboomet som en fortid præget af slaveri, en tid, de nu har lagt bag sig. Nu ser de sig selv som ,civiliserede“, forstået som folk, der tidligere var underlagt en stor hacienda - som slaver, og som (derfor) taler spansk og har gået i skole i modsætning til indianere som fx asháninka, der ses som ikke-civiliserede, og som „lever i skoven“(Gow 1991:50, 69). Asháninka har ikke på tilsvarende vis konstrueret en identitet, der har gummiboomet som fælles negativ eller positiv erfaringsramme. Dette har intet at gøre med henholdsvis yines og asháninkas respektive roller under gummiboomet. Det var nemlig aldrig sådan, at yine systematisk var ofre og asháninka fortrinsvis banditterne. Det var snarere omvendt. Yine var længe kendt som dygtige handelsfolk, og de gik uden skrupler ind i slavehandelen, da det var der, der var noget at tjene. Det var yine, som var kendt for at terrorisere asháninka i slutningen af 1800tallet (Samanez y Ocampo 1980:66), ligesom det var yine, der systematisk plyndrede og overfaldt machiguengabopladserne langs Urubambas bifloder (Gow 1991). Yine ser sig $\mathrm{i}$ dag som civiliserede, og dermed ,frigjorte“ $\mathrm{i}$ kraft af denne fortid, hvis vi skal tro Peter Gow. Blandt asháninka er billedet anderledes broget, som vi har set. Her lægges ikke særlig vægt på spørgsmålet om, hvorvidt man er civiliseret eller ej, og erindringerne om fortiden i Ucayali har kun relevans for ens personlige identitet, ikke for den etniske identitet. Til gengæld er den aktuelle politiske situation særdeles relevant for, hvordan asháninkas historier fortælles. For selvom gummiboomet ophørte, fungerede gældsslaveriet i Ucayali langt ind i 1980'erne og 1990'erne, og visse steder fortsætter det stadig, nu knyttet til andre produktioner end gummi. Deciderede bortførelser synes at have gået for sig til langt ind i 1950'erne, hvor der efter sigende fungerede et åbent slavemarked i Atalaya.

Da jeg hørte Bernardos historie første gang, fremkaldte det ubesvarede spørgsmål om, hvad der blev af den lille Eliceo, et billede i min egen erindring af de forskellige henvendelser, jeg selv fik fra flere mig aldeles ukendte indianere for 17 år siden. Dengang boede jeg en tid i Atalaya, mens jeg ventede på en floddamper, der kunne sejle mig selv og min familie ned ad floden til Pucallpa, hovedstad i datidens Ucayali,,departement“. Disse personer havde hørt, at vi, de fremmede ,gringoer“, kom inde fra Gran Pajonal, i folkemunde anset for de „vilde“ ashéninkas højborg, og nu ville de lige høre, om vi mon havde set noget til en person af dette eller hint navn? Den eftersøgte person var nemlig en broder eller søster eller anden nær slægtning, som var blevet bortført som barn fra Perené længere mod vest, og man vidste, at bortførerne var gået østover, ind over Gran Pajonal, for at nå frem til Ucayali. Og det kunne jo være, at vedkommende broder eller søster stadig befandt sig i området, og det kunne jo tænkes, at vi havde mødt vedkommende. Vi måtte hver gang beklage, at, nej desværre, vi havde ikke mødt nævnte broder eller søster inde i Gran Pajonal. Til gengæld var vi blevet opsøgt af en kvinde med et barn, som havde sagt, at hun kom fra Ucayali og var løbet bort fra sin patron, som var fader til barnet, og hos hvem hun havde været slave i årevis. Hun kom for at bede om medicin til barnet, og da vi spurgte, hvad hun lavede i Gran Pajonal, sagde hun, at hun havde søgt tilflugt her, fordi hun mente, at patronen aldrig ville kunne nå hende her.

Siden blev vi selv vidner til en episode, hvor en patron med to sværtbevæbnede politimænd ankom i en hurtig motorbåd til Chicosa, en ashéninkalandsby ved en biflod til Ucayali, på jagt efter en lille familie, som de påstod var bortløbne arbejdere, der skyldte 
arbejde, som de havde modtaget forudbetaling for. Gældsslaveri er forbudt ved lov i Peru, så det var ikke helt klart, hvad det var, de uniformerede politifolk bestilte under patronens kommando, ud over at her var tale om anskuelsesundervisning i et forhold, som enhver tog for givet på den tid, nemlig at patronerne ,ejede“ det lokale politi og alle offentlige myndigheder. De undvegne var tydeligvis rædselsslagne, og det var deres høje skrig og de øvrige forsamlede indianeres råb og palaver, der havde fået os til at komme løbende ned til flodbredden for at finde ud af, hvad der var på færde. Patronen var en nydelig dame af tydelig europæisk herkomst, ren, velklædt og velplejet, af en type, man kunne møde på hovedstrøget i Limas rigmandskvarter eller i Illums Bolighus i København for den sags skyld. Vore veje havde krydsedes tidligere på floden, hvor vi kom sejlende med nogle indianere $\mathrm{i}$ en udhulet træstamme med hjælpemotor, og hun kom forbi i sin hvidskurede motorbåd med bådfører, siddende foran i fartøjet iført skinnende ren nystrøget skjorte og udslået parasol som værn mod den skarpe sol. Hun havde høfligt tilbudt os et lift, som gringo til gringo, åbenbart ud fra en idé om, at det ikke anstod sig for ,,vores slags“ at lade sig transportere på så primitiv vis. Vi havde høfligt afslået gæstfriheden og konverseret fruen behørigt. Det kom noget bag på os, at den venlige dame nu viste sig også at være en af de patroner, som indianerne hele tiden talte om.

Men alt det var i 1986 og 1987. Næsten 20 år senere havde tingene ændret sig, ikke mindst takket være AIDESEP, ${ }^{23}$ en paraplyorganisation for Perus amazoniske grupper og landets største indianske organisation. Da AIDESEP greb ind og afslørede gældsslaverisystemet sidst i 1980'erne, stod indianerne frem og vidnede mod patroner og embedsmænd, som var involveret $i$ opretholdelsen af misbruget. Miqueas Mishari, en af mine informanter, var på den tid forsvarssekretær i AIDESEP, og som asháninka blev det ham, der fik til opgave at mobilisere indianerne i Ucayali for at gøre en ende på systemet. Miqueas fortæller:

Jeg fik til opgave at rejse til provinsen Atalaya i januar 1986 for at undersøge nogle klager, vi havde fået mundtligt fra en næsten 80 -årig asháninka, Ricardo Marinero i Ucayali. [...] over at skrupelløse nybyggere og jordspekulanter systematisk havde frarøvet indianerne jorden. [...] Jeg rejste rundt og besøgte flere lokalsamfund og opdagede, at Atalaya var et ingenmandsland, hvor der foregik alle slags krænkelser af menneskerettighederne, og hvor tømmerpatroner, kvægholdere og store jordejere gjorde sig velhavende gennem slavegjorte asháninkas arbejde. [...] Vi fandt ud af, at mere end 6000 familier havde levet i slaveri i mindst 40-50 år. Mange var døde under arbejdet, var blevet mishandlet og havde fået tuberkulose. Mange børn var døde af malaria eller var blevet blinde, halte, uden ben. Når nogen kom til skade under tømmerhugst, drak patronen dem fulde, og så blev de slået ihjel for at spare udgifterne til lægebehandling.

De informationsmøder, Miqueas indkaldte til, måtte arrangeres i dyb hemmelighed. Patronerne måtte ikke vide noget. Miqueas forklarede i første omgang indianerne ude i området om de rettigheder, de faktisk havde ifølge landets love. Det var helt nyt for dem. Efter et halvt år, hvor nyheden i det skjulte gik fra mund til mund, blev der indkaldt til et fællesmøde i Atalaya. Først da gik det op for patronerne, hvad der foregik. Sagerne mod dem kom til at cirkulere hos myndighederne i Lima gennem flere år. For at slippe for den uønskede aktivist og undgå videre sagsanlæg hyrede patronerne nogle lejemordere, som skulle gøre det af med Miqueas Mishari. Bagefter kunne de altid sige, at det var terrorister fra Den Lysende Sti, som havde gjort det. Miqueas fandt ud af det, fordi hans kusine, som havde et værtshus, hvor lejemorderne mødtes for at drikke øl, havde overhørt transaktionen. Hun advarede Miqueas: „Hvorfor er du kommet, fætter? De vil slå dig ihjel 
i dag. I går aftes fik lejemorderne fra Sepa, straffekolonien, 3000 soles. “Hun havde grædt og omfavnet Miqueas: „Skynd dig væk, lillebror, skynd dig væk! Jeg vil ikke have, du skal dø!“ Men Miqueas løb ikke sin vej, fortæller han. I stedet sørgede han for, at han altid var omgivet af mindst 20 indianere, som passede på ham. Lejemorderne overfaldt $\mathrm{i}$ stedet AIDESEPs udsendte advokat, mens han lå og sov. Heldigvis gjorde de ham ikke noget, da de opdagede, at det var den forkerte, de havde fat i. De kom efter Miqueas et par gange om natten, men de fandt ham aldrig. Han sov nemlig aldrig det samme sted to nætter i træk, når han besøgte området. Patronerne indgav også en falsk anklage mod ham og et par andre indianske ledere for terrorisme. Det fik de nu ikke noget ud af, for AIDESEP havde indberettet hele provinsadministrationen - fredsdommerne, subpræfekten, politiet og direktøren for landbrugsministeriets afdeling i Atalaya - til Statens Kontor for Indianske Anliggender (Instituto Indigenista Peruano), til Arbejdsministeriet og til ILO for at have rottet sig sammen med patronerne og jordejerne. Alle embedsmændene blev sat fra bestillingen og udskiftet, fordi de i årevis havde set igennem fingre med krænkelserne og ladet, som om indianerne i Atalayaprovinsen slet ikke eksisterede. Efterfølgende bestemte en ministeriel resolution, at indianerne skulle tilkendes jord.

I praksis betød det en revolution i Atalaya. For den besøgende blev det tydeligt i byens gadebillede. Hvor det i 1980'erne havde været yderst sjældent at møde indianere i Atalaya, selvom de udgjorde den demografiske majoritet i området, var der i 2004 masser af indianere i byen, besøgende såvel som fastboende. I 1980'erne havde ,almindelige“ indianere ikke turdet bevæge sig rundt i Atalaya, især ikke, hvis de ikke ejede pænt tøj og talte dårligt spansk, hvorved de signalerede en magtesløshed, der indbød til misbrug. Det havde de været meget bevidste om. Alt det var ændret, i og med at det var blevet slået fast, at indianere har rettigheder ifølge loven. Dermed ikke sagt, at alt nu er fred og idyl; det er det ikke - slet ikke! Men det er der ikke mulighed for at komme videre ind på her. Pointen er, at indianerne er kommet på banen som aktører i det offentlige rum; deres stemmer tæller ved valgurnerne, og de er mange nok til, at det virkelig kan mærkes rent lokalpolitisk. Det ved de godt, og det er de i fuld gang med at finde ud af at udnytte.

At tingene ændres, betyder imidlertid ikke, som vi har set, at bevidstheden om fortiden forsvinder fra den kollektive diskurs, snarere tværtimod. At der måske ikke længere foregår slet skjult slaveri i stor stil på patronernes store ejendomme i Ucayali, betyder ikke, at indianerne har glemt, hvad slaveri, mishandlinger og misbrug af arbejdskraft vil sige, som Bernardos og Adolfos historier vidner om. Der ligger tydeligvis i samtiden en politisk interesse $\mathrm{i}$ at tale åbent om patronernes misgerninger. Det gør formentlig også fortællingerne om Bernardos og Adolfos forældre og bedsteforældre fortællelige på en anden måde, end tilfældet ville have været, hvis det stadig var forbundet med livsfare at kritisere patronerne. Spørgsmålet er, hvad det er, der huskes, og hvad det bruges til, når det fortælles. Selvom erindringerne ikke slet og ret udgør vidnesbyrd om, „hvad der virkelig skete“, og selvom de heller ikke placerer asháninka entydigt på den samme side i en „vi““-skabende os-demdikotomi, så udgør de stadig narrativer, der giver mening i forlængelse af diskurser og politiske problemfelter i samtiden. At erindringer om fortiden i grunden lige så meget er refleksioner af nutiden, er blevet problematiseret i mange sammenhænge - af historikere, der ønsker at bestemme orale traditioners validitet som historisk kildemateriale, af dommere og advokater, som undersøger vidneudsagns sandhedsværdi, af antropologer, som har undersøgt dannelsen af individuel og kollektiv identitet, og erindringsforskere, som vil kende den menneskelige hukommelses måde at fungere på. 
Blandt historikere har der udfoldet sig ophedede debatter, dels om hvorvidt orale traditioner kan tilføje historievidenskaben noget som helst nyt, og dels om hvorvidt almindelige menneskers erindringer og mundtligt overleverede familiehistorier kan gælde som historiske vidnesbyrd. For dem, som er interesserede $\mathrm{i}$ at udvikle et perspektiv på historien „set nedefra“, dvs. set fra almindelige menneskers position, er ukonventionelle vidnesbyrd af denne type næsten uomgængelige, men som „kilder“ må de naturligvis læses med kritiske øjne - som det gælder alle typer kildemateriale. Hvordan man bærer sig ad med det, er blevet diskuteret af blandt andet Jan Vansina og Paul Thompson, prominente foregangsmænd inden for brugen af mundtlige overleveringer i historieskrivningen. Vansina, belgisk historiker og antropolog med afrikanske orale traditioner som speciale, definerede i sin tid oral tradition som "mundtlige vidnesbyrd overført verbalt fra generation til generation" (Vansina 1965). Vansina viste, hvordan oral tradition læst med kritisk omhu og med visse begrænsninger kan bruges i historieforskningen både i kontekster, hvor de udgør de eneste kilder til viden om historien, og i sammenhænge, hvor de kan krydstjekkes med andre, nedskrevne, kilder. I det sidste tilfælde, som også synes at være de fleste tilfælde, viser de orale traditioner sig oftest at kunne bidrage med ikke blot supplerende viden i forhold til det allerede kendte. De udgør også - og mere vigtigt korrektiver hertil. De repræsenterer alternative perspektiver på bestemte historier eller historiske forløb (se fx Prins 1991:115-6, 129). Af samme grund sætter forsøget på at se historien ,nedefra“ brugen af orale traditioner, især personlige erindringer og familiehistorier, i fokus. At der i mange tilfælde heller ikke findes ret mange andre typer af vidnesbyrd at trække på, giver så meget desto mere grund til at dyrke de orale traditioner som kilder. ${ }^{24}$ For disse historikere er det således klart, at hvis der skal kunne etableres historieskrivning om, af eller for de „historieløse“ (i den 3. og 4. verden) og for de „tavse“ (småkårsfolk, arbejderklasse, kvinder, politiske dissidenter og andre i vor 1. og 2. verden), må vejen nødvendigvis gå over orale traditioner i en eller anden form (Sharpe 1991). Men som nævnt må de anvendes med forsigtighed og helst krydstjekkes med andre typer af kilder til viden, historiske og etnografiske, hvorved man samtidig kan udskille både forekomsten af „opfundne traditioner“ (invented traditions) i Hobsbawms og Rangers forstand (1983) og de lokale narrative genrer, som fortællinger skriver sig ind i, og hvis formsprog i sig selv er betydningsbærende.

\section{Erindringernes narrative struktur}

I det perspektiv er det mest interessante ikke at finde ud af, om fx detaljerne i Bernardos historie om bedstefader Mokatzari og den stakkels Eliceo er historisk korrekte. Det er trods alt en historie, han har fra sin moder, som har fortalt ham noget, hun oplevede, da hun var en lille pige. Og hun har fortalt det til sin søn, mens han stadig var meget ung. Forældrene skiltes nemlig, da Bernardo ikke var mere end ni år gammel, og som det er vanligt blandt asháninka, blev børnene anbragt hos nogle slægtninge. Det er altså en erindring om noget, et barn har oplevet og fortalt videre mange år senere til et andet barn, som endnu senere fortæller det videre til en helt fremmed, antropologen. Hvor pålidelig er den historie? Som sandhedsvidnesbyrd er den måske ikke meget bevendt. Men hvad er den så udtryk for? Vi ved med sikkerhed, at den slags ting, Bernardo og Adolfo fortæller om, er foregået i området på den tid, hvor deres bedstefader/fader levede. Så 
fortællingerne kunne godt være sande. Men vi ved også, at erindringer er gjort af meget andet stof end netop affotograferingen af, ,hvad der virkelig skete“. Og antropologen kender sine informanter godt nok til at vide, at deres historier ligger i forlængelse af en lokal fortælletradition, som kæler for detaljerne og for det dramatiske, og som gerne opdaterer en fortællings elementer, så de passer til den situation, der fortælles i, og til de tilhørere, der lytter på og aktivt fortæller med på historien. Bernardo er en god fortæller, der holder af at brodere videre på historier, han finder en tand for kedelige. Hvor meget af historien om Mokatzari er noget, han selv har føjet til det, hans moder fortalte ham for næsten 50 år siden? Årstallene har han selv sat på, detaljerne om de farlige rovdyr og sumpenes giftige kryb skriver næsten sig selv. Enhver, som kender området, vil se beskrivelsen som en autentisk fremstilling af de naturgivne betingelser, som næppe har ændret sig meget, siden Mokatzari flygtede gennem sumpene. Og detaljerne bliver jo ikke mindre dramatiske af at blive fortalt. Men hvis ikke fortællingerne slet og ret er sandheden om, „hvad der virkelig skete“, og hvis en god del af fortællingernes indhold er illustrerende „fyld“, som er medtaget af narrative hensyn, hvad er det så egentlig, at fortællingerne giver os? Hvad er deres betydning som erindringer og historiebærende fortællinger?

For de erindringer om Ucayali, vi har set på her, er den vigtigste fortolkningskontekst måske netop den politiske situation, der aktuelt eksisterer i den samtid, de fortælles i. Den magt, som patronerne opbyggede for sig selv under gummiboomet, er kun for nylig blevet modificeret, og det er kun sket i kraft af indianernes politiske organisering, som for asháninkas vedkommende tog sin begyndelse i Perené i 1970'erne, mens det først er sket blandt asháninka i Ucayali mere end et tiår senere. Organiseringen blev forstærket i 1990'erne i kraft af oprettelsen af selvforsvarsmilitser, der kunne gå imod terroristerne fra Den Lysende Sti. Og her var det primært asháninka og ikke yine, shipibo eller andre, som udgjorde den politisk aktive drivkraft set fra asháninkas eget synspunkt. Den energi og vilje til handlen, dette er udtryk for, er i høj grad del af asháninkas kollektive selvbillede, som det fremgår af de biografiske fortællinger, jeg har samlet.

Men hvordan går det så til, at mange asháninka i perioder tilsyneladende affinder sig med at være objekter for misbrug fra patronernes side? Der er jo intet, der tyder på, at de finder det ulige forhold ,naturligt“ eller rimeligt. De har på ingen måde internaliseret en mentalitet som undergivne, og der skal ikke meget til, før de pludselig sætter sig i bevægelse. Det sker, når en missionær, en oprørsleder eller en anden ildsjæl, som kan være asháninka eller en person af anden etnisk oprindelse, udkaster en idé, som inspirerer. Så er det, ordene lyder blandt folk: „Aate, thame aate!“ - „Kom! Lad os ..." eller „Kom, nu går vi!““. Ordene er ikke blot dele af et narrativ, en måde at fortælle på. Ordene er et signal til handling i dagligdagen.

I Adolfos fortælling om faderen, er det faderen, der siger ordene: „Lad os rejse væk!““ „Thame aate!" - og så rejser hele familien langt bort fra det sted, hvor de har tilbragt det meste af deres liv. Faderen har i årevis handlet med geværer - på vegne af patronen, og er trofast forblevet på sin plads uden at løbe bort, selvom han teoretisk set kunne have gjort det. Tilsvarende opsøger Bernardos bedstefader af egen fri vilje mestizer/patroner i Ucayali for at tage arbejde for dem. Hvorfor? Fortælleren giver selv svaret; en fætter opfordrede Mokatzari til at rejse med til Ucayali: „Aate, thame aate!“ Bernardos bedstefader havde tænkeligt - ligesom de fleste andre asháninka - et ønske om at erhverve sig et gevær og andre varer, som kun kunne opnås via patronerne. Sådanne varer blev tidligt et nødvendigt element $\mathrm{i}$ indianernes sociale reproduktion. Omkostningerne ved at skaffe dem var høje. 
De mænd, som havde mod til at udsætte sig for de farer, som var forbundet med nærkontakten med de fremmede, patronerne, er derfor ikke ofre i asháninkas historier. De er banditter, der en gang imellem bliver til en slags helte, som vover sig ind i fremmed område for at sikre adgangen til ressourcer, der vil optimere den sociale reproduktion hos deres egne i ,koloniale situationer“" ${ }^{25}$ hvor uafhængig tribal selvtilstrækkelighed langt ude i skoven ikke er et viabelt alternativ. Men vovemodet og nærkontakten med vold og død har en pris, som Mokatzaris og Andrés Gutierrez' skæbner er billeder på. De betaler med deres liv, for at fred og ro kan genoprettes, og deres efterkommere kan leve videre og finde deres egne veje gennem verden under de nye betingelser, forgængernes ofre har skabt. På den måde bliver de to familiehistorier parabler på både asháninkas situation generelt og på henholdsvis Bernardos og Adolfos egne selvbilleder som ledere, mænd, der tager initiativer og fører an $i$ organiseringen af deres eget samfund. Historien, de erindrede erfaringer, som forældrene og bedsteforældrene gjorde sig og fortalte om, bærer de med sig, og det er den historie, de handler på. Det er på basis af den historie - og den kulturelt betingede narrative ordning, den følger, for at blive til historie - at fortællingen bliver handlingsanvisende i den situation, hvor den fortælles. På den måde er den lille Eliceo - det bortførte barn - måske alligevel ikke helt tabt.

Det er ikke tilfældigt, at vore fortællere konstruerer deres fortællinger, som de gør. Deres fortællinger om Ucayali ordner fortiden i sekvenser af begivenheder - begivenheder, som ,gør" noget i forhold til temaer som flugt, bortførelser, kampe, rejser mod det ukendte og død eller trusler om død som en forudsætning for genoprettelse af ro og orden, så samfundet kan reproduceres. De samme temaer går igen i asháninkamytologier, som vi ikke skal yderligere ind på her. Pointen er blot, at fortællingerne klart ordner erindringerne efter velkendte asháninkamodeller for, hvordan verden er indrettet. På deres mest elementære niveau er historierne ordnet som begivenhedssekvenser, hvor handling følger på handling med asháninka som aktører i fokus. Disse narrative strukturer, som karakteriserer såvel Bernardos og Adolfos familiehistorier som Miqueas' personlige erindringer om Ucayali, reflekterer måderne, hvorpå asháninka kodificerer deres eget samfunds grundlæggende reproduktive strukturer. Kodificeringerne afspejles i fortællingernes form såvel som i deres indhold; og både form og indhold er betydningsbærende og betydningsgenererende, $\mathrm{i}$ den forstand at de udgør fortællernes midler til at forklare sig selv både over for dem selv og over for tilhørerne - og læserne. Levede asháninkaliv, -handlinger og -erindringer bliver sat på form og får mening netop gennem at blive ordnet og fortalt på måder, som tilhørerne genkender.

Det er her, på formsiden og ikke på indholdet, at asháninkas erindringer om Ucayali adskiller sig markant fra historieskrivningens og etnografiens fremstillinger af samme forhold i samme region og epoke. Historikernes og antropologernes Ucayali handler om gummiboomets og gældsslaveriets økonomiske strukturer, om arbejdets organisering, om omfanget og fordelingen af udenlandske investeringer, eksportens omfang, markedets fluktuationer og patronernes indbyrdes netværk. I den historie er indianerne nogle, der bliver handlet på og med - i bogstaveligste forstand. I asháninkas fortællinger er de selv aktive hovedpersoner, som finder deres egne veje og indretter livsrum for sig selv. Erindringerne bliver dermed til budskaber om, at verden ikke blev skabt af patroner og gringoer, der faldt ned fra himlen. Den blev skabt af asháninka, som tog sagerne i egne hænder og brød op og ud. Som sådan bliver erindringerne til meddelelser om, at fremtiden og nutiden ligger åben for videre handling for dem, der tør og vil. Gennem at blive fortalt får erindringerne 
plads i den fælles hukommelse, og menneskene tager plads i historien. Gennem at huske og fortælle indtager de verden på ny.

\section{Noter}

1. Udtrykket „,de historieløse folk“ er ikke Wolfs opfindelse. Det har været brugt af andre før ham. Lévi-Strauss kaldte 20 år tidligere udtrykket for klodset og mente, det burde erstattes af hans eget begreb om de „kolde“ samfund, dvs. samfund, som var indrettet på at forblive statiske, uforanderlige og derfor historieløse (1966:233-4). Dette Lévi-Strauss'ske koncept er siden blevet kritiseret fra mange sider (se fx Hill 1988).

2. Ardener (1989).

3. Dialektforskelle og interne politiske uoverensstemmelser gør, at der i praksis skelnes mellem asháninka og ashéninka. I mangel af fælles generisk betegnelse og for overskuelighedens skyld refereres der her til dem alle under ét som asháninka (se også Hvalkof \& Veber 2005).

4. Decreto Ley 20653 de 1974, Ley de Comunidades Nativas y de Promoción Agropecuaria de las Regiones de Selva y Caja de Selva. Loven om indfødte fællesskaber og landbrugsudvikling i regnskovens regiones, givet i 1974 under det venstreorienterede militærstyre ledet af general Juan Velasco Alvarado.

5. Familiehistorierne og andre erindringer, som udgør basis for denne artikel, er indsamlet i efteråret 2004 og 2005 i forbindelse med et forskningsprojekt finansieret af Statens Humanistiske Forskningsråd med titlen ,Mellem to verdener. Amazonindianske selvforståelser i ombrydningen af globale muligheder og lokale magtforhold set gennem fire asháninkalederes biografier“. De biografiske fortællinger er under udgivelse på spansk under titlen „Historias de Vida“ (Veber n.d.)

6. Denne og artiklens øvrige empiricitater er egne oversættelser fra de spanske originalversioner optaget i efteråret 2004 .

7. Mankoite betegner en lokalitet i Gran Pajonal, et regnskovsdækket plateau i baglandet mellem floderne Tambo, Ucayali og Pichis i Perus centrale Amazonas. Indianerne i Gran Pajonal betegner sig selv som ashéninka.

8. Masato er hjemmebrygget øl fremstillet på basis af maniok, se Veber (1999).

9. Adventistmissionen i Perus Selva Central blev startet i 1922 af amerikaneren Fernando Stahl, som fik lov at anlægge sin mission blandt indianerne på en stor kaffeplantage i det øvre Perené under det britiskejede selskab Peruvian Corporation Ltd. Aftalen indebar, at missionen skulle opdrage indianerne til stabil og pålidelig arbejdskraft for plantagen. Efter uoverensstemmelser blev missionen siden flyttet længere østpå mod lavlandet. Missionen i Sutziki blev anlagt i 1930 (se også Veber 1991).

10. I Peru bruges i folkemunde betegnelsen „gringo“ om personer af europæisk/kaukasisk/,hvid“ fænotype uanset herkomst eller nationalt tilhørsforhold.

11. En ekstraktiv økonomisk front kendetegnes ved udvinding af råstof eller råvarer til eksport, som ikke følges af indkomstgenererende lokal forarbejdning af råstofferne ligesom sikring af det udvundne råstofs regenerering $\mathrm{i}$ reglen heller ikke er med i billedet.

12. Se Hvalkof (1998, 2006).

13. Yánesha udgør en indiansk befolkning på lidt over 9000 (tal fra år 2000) i området sydvest for floden Palcazu. De kendes i ældre litteratur som „amuesha“, se Santos Granero (2004).

14. Gummiboomet var på sit højeste i tiden 1860-1915, men gummiindsamling i mindre omfang foregik og foregår både før og efter disse årstal. Se også Santos Granero og Barclay (2000).

15. Det spanske ord patron henviser i Peru til en arbejdsgiver, godsejer, herremand eller slet og ret ejermand. Ordet gengives uoversat i mangel af adækvat terminologi på dansk. 
16. Gummiboomet betegner på sæt og vis en indianske holocaust - hvis man må have lov at bruge denne betegnelse på dette scenarium. Det skønnes, at hundrede tusinder af indianere blev underlagt et veritabelt terrorregime fra patronernes side. I Putumayo i grænseområdet mellem Peru og Colombia kostede gummiboomet mindst 30.000 indianere livet i løbet af de 25 år, hvor eventyret var på sit højeste. Her er tale om et område, der omfatter en enkelt koncession i et enkelt flodområde, hvor rædslerne kom til offentlighedens kendskab. En lignende bevågenhed blev ikke Ucayali til del, og om rædslerne nåede samme omfang her som i Putumayo, kan næppe opklares (se også Hvalkof 2000).

17. Ud fra en umiddelbar betragtning forekommer det mig, at beretningerne om „store krigere“ gerne ender med, at disse bliver dræbt af andre „mindre“ krigere, som så selv bliver store, se fx fortællingerne udgivet af Fernández (1986).

18. Forfatteren udførte i perioden 1985-87 etnografisk feltarbejde blandt ashéninkaindianerne i Gran Pajonal med nogle kortere feltstudier i Unini og Chicosa, sidefloder til Ucayali. Projektet var finansieret af Forskningsrådet for Udviklingsforskning og Statens Humanistiske Forskningsråd.

19. Igennem 1990'erne var asháninka og alle øvrige befolkninger i det centrale Peru berørt af væbnede konflikter og terrorhandlinger afstedkommet som følge af tilstedeværelsen af oprørsbevægelserne Den Lysende Sti (Sendero Luminoso, SL) og MRTA (Movimiento Revolucionario Túpac Amaru). Mange asháninka organiserede egne selvforsvarsmilitser. Nogle blev tvangsrekrutteret af SL, andre gik frivilligt ind i enten SL eller MRTA. Det anslås, at konflikterne kostede 6000 asháninka livet, 10.000 internt fordrevne, og 5000 blev holdt som fanger/arbejdskraft af SL. Mellem 30 og 40 asháninkalokalsamfund ophørte med at eksistere (Comisión de la Verdad y Reconciliación 2003:241).

20. Movimiento de Izquierda Revolucionaria, en venstreorienteret guerillabevægelse i Peru i 1960'erne inspireret af Fidel Castro og Che Guevara (se Brown \& Fernández 1991).

21. Vicente Naco sad efterfølgende fængslet i Lima i to år. Her lærte han at tale spansk.

22. En del af koloniseringen af Selva Central skyldtes europæiske immigranter, som i sidste halvdel af 1800-tallet fik tildelt store jordområder på fordelagtige vilkår. Man mente fra officielt hold, at importen af europæere ville gavne udviklingen og ,forbedre racen“. De tyske nybyggere kom især fra Prøjsen og Tyrol (Santos Granero \& Barclay 1998).

23. Asociación Interétnica del Desarrollo de la Selva Peruana (Den Interetniske Sammenslutning til Udvikling i den Peruanske Regnskov) blev grundlagt i 1980'erne.

24. Materiel kultur og billeder af enhver art kan udgøre andre alternative og supplerende kilder til historisk viden. Men også her gælder det, at en adækvat kildekritisk metodik må udvikles, før alle vanskeligheder kan siges at være løst (se bl.a. Burke 1991:13).

25. T. Turner bruger udtrykket „koloniale situationer“ om kontekster karakteriseret ved dominansforhold, hvor befolkninger, som er etnisk og kulturelt forskellige, sameksisterer inden for samme (analytiske) felt forenet af diametralt modsatte om end indbyrdes afhængige interesser (Turner 1988:239-40).

\section{Litteratur}

Anderson, Benedict

$2001 \quad$ Forestillede fællesskaber. Refleksioner over nationalismens oprindelse og udbredelse. Frederiksberg: Roskilde Universitetsforlag.

Ardener, Edwin

1989 The "Problem" Revisited. I: M. Chapman (ed.): The Voice of Prophecy and Other Essays. Oxford: Basil Blackwell.

Brown, Michael F. \& Eduardo Fernández

$1991 \quad$ War of Shadows. The Struggle for Utopia in the Peruvian Amazon.

Berkeley: University of California Press. 
Comisión de la Verdad y Reconciliación

2003 Informe Final de la Comisión de la Verdad y Reconciliación. Vol. V.

Lima: Oficina de Comunicaciones e Impacto Público.

Burke, Peter

1991 Overture: The New History, its Past and its Future. I: P. Burke (ed.): New

Perspectives on Historical Writing. Cambridge: Polity Press.

Fernández, Eduardo

1986 Para que nuestra historia no se pierda. Testimonios de los Asháninca y

Nomatsiguenga sobre la colonización de la región Satipo-Pangoa. Documento 7.

Lima: CIPA.

Gow, Peter

1991 Of Mixed Blood. Kinship and History in Peruvian Amazonia. Oxford: Clarendon Press.

Hastrup, Kirsten

1999 Viljen til viden. En humanistisk grundbog. København: Gyldendal.

Hill, Jonathan D.

1988 Introduction: Myth and History. I: J.D. Hill (ed.): Rethinking History and Myth. Indigenous South American Perspectives on the Past. Urbana: University of Illinois Press.

Hobsbawm, Eric \& Terence Ranger (eds.)

1983 The Invention of Tradition. Cambridge University Press.

Hoffmann, Odile

2002 Collective Memory and Ethnic Identities in the Colombian Pacific. Journal of Latin American Anthropology 7(2):118-38.

Hvalkof, Søren

1998 From Slavery to Democracy: The Indigenous Process of Upper Ucayali and Gran Pajonal. I: A. Parellada \& S. Hvalkof (eds.): Liberation through Land Rights in the Peruvian Amazon. IWGIA Document No. 90. København: IWGIA.

2000 Outrage in Rubber and Oil: Extractivism, Indigenous Peoples, and Justice in the Upper Amazon. I: C. Zerner (ed.): People, Plants and Justice. The Politics of Nature Conservation. New York: Columbia University Press.

2004 Place, People and History. I: S. Hvalkof (ed.): Dreams Coming True ... An Indigenous Health Programme in the Peruvian Amazon. København: Nordeco.

2006 Colonization and Conflict on the Amazon Frontier: Dimensions of Interethnic Relations in the Peruvian Montaña. I: D. Geiger (ed.): Frontier Encounters: Indigenous Communities and Settlers in Asia and Latin America. København: IWGIA.

Hvalkof, Søren \& Hanne Veber

2005 Los Ashéninka del Gran Pajonal. I: F. Barclay \& F. Santos Granero (eds.): Guía Etnográfica de la Alta Amazonia. Vol 5. Lima: Smithsonian Tropical Research Institute \& Instituto Francés de Estudios Andinos.

Jackson, Michael

2002 The Politics of Storytelling. Violence, Transgression and Intersubjectivity. København: Museum Tusculanum Press.

Jensen, Bernard Eric

2005/2006 Harald Welzer som erindringsforsker. En viderefører af Halbwachs-Assmanntraditionen? Tidsskriftet Antropologi 52:17-39.

Lévi-Strauss, Claude

1966 The Savage Mind. Chicago: University of Chicago Press.

Prins, Gwyn

1991

Oral History. I: P. Burke (ed.): New Perspectives on Historical Writing.

Cambridge: Polity Press. 
Sala, P.Fr. Gabriel

$1925 \quad$ Apuntes de Viaje del P. Fr. Gabriel Sala. Exploracion de los Rios Pichis, Pachitea y Alto Ucayali y de la Region del Gran Pajonal 1897. I: F.B. Izaguirre (ed.): Historia de las Misiones Franciscanas 1619-1921. Vol. 10, Part 3. Lima: Talleres

Tipográficos de la Penitenciaria.

Samanez y Ocampo, Jose B.

1980 Exploracion de los Rios Peruanos Apurimac, Eni, Tambo, Ucayali y Urubamba hecha en 1883 y 1884. Diario de la expedicion y Anexos. Lima.

Santos Granero, Fernando

2004 Los Yánesha. I: F. Barclay \& F. Santos Granero (eds.): Guía Etnográfica de la Alta Amazonia. Vol 4. Smithsonian Tropical Research Institute \& Instituto Francés de Estudios Andinos. Lima.

Santos Granero, Fernando \& Frederica Barclay

1998 Selva Central: History, Economy, and Land Use in Peruvian Aamzonia. Washington: Smithsonian Institution Press.

2000 Tamed Frontiers. Economy, Society, and Civil Rights in Upper Amazonia. Boulder: Westview Press.

Sharpe, Jim

1991 History from Below. I: P. Burke (ed.): New Perspectives on Historical Writing. Cambridge: Polity Press.

Turner, Terence

1988 Ethno-Ethnohistory: Myth and History in Native South American Representations of Contact with Western Society. I: J.D. Hill (ed.): Rethinking History and Myth. Indigenous South American Perspectives on the Past. Urbana: University of Illinois Press.

Valcarcel, Daniel

1946 Rebeliones Indígenas. Lima: Editorial P.T.C.M.

Vansina, Jan

1965 Oral Tradition. A Study in Historical Methodology. London: Routledge \& Kegan Paul.

Veber, Hanne

1991 Hvordan Gud kom til asháninka. Adventistmissionen i peruansk Amazonas. Tidsskriftet Antropologi 23:61-87.

1999 Masatodrikningens sociale rum. Ashéninkasamfundet i Gran Pajonal. Tidsskriftet Antropologi 39:199-213.

2003 Asháninka Messianism: The Production of a Black Hole' in Western Amazonian Ethnography. Current Anthropology 44(2):183-211.

n.d. Historias de Vida. København: IWGIA (under udgivelse).

Whitehead, Neil L.

2003 Introduction. I: N.L. Whitehead (ed.): Histories and Historicities in Amazonia.

Wolf, Eric R. Lincoln: University of Nebraska Press.

1982 Europe and the People without History. Berkeley: University of California Press. 